\title{
IS LIPSTICK ORAL HEALTH?
}

The BDJ Upfront section includes editorials, letters, news, book reviews and interviews.

Please direct your correspondence to the News Editor, David Westgarth at the BDJ, The Macmillan Building, 4 Crinan Street, London, N1 9XW or by email to BDJNews@nature.com

Press releases or articles may be edited, and should include a colour photograph if possible.

Stephen Hancocks OBE

Editor-in-Chief

$\mathrm{T}$ he General Dental Council (GDC), in its professed purpose of protecting patients, takes steps to prosecute people who are deemed to be unlawfully practising dentistry, that is without being registered with the Council as a dental professional. In recent years this has primarily been those who have been providing tooth whitening, usually at salons in the form of beauty treatments, spa experiences and the like.

Taking great glee in announcing each conviction with the issuing of a press release, the GDC seems to be finding itself increasingly involved in the process and using the money from our annual retention fees to do so. This is of course quite proper, but one may be prompted to ask why their apparently vigorous prosecution of so many alleged transgressors seems to have no deterrent effect? Taking a recent case as an example, the defendant was accused at Lancaster Magistrates' Court of unlawfully practising dentistry, namely tooth whitening, contrary to Section 38 (1) and (2) of the Dentists Act 1984. After pleading guilty she was sentenced to a 12 month conditional discharge and ordered to pay a £15 victim surcharge. In addition, she had to 'pay £250 compensation to the victim for pain and suffering and $£ 65$ compensation to the victim for re-imbursement of the cost of the treatment. She has also been ordered to pay costs to the GDC of $£ 1468.63$.'

This is serious for the person concerned, but at a total of $£ 1,798.63$ (just over two annual retention fees for a dentist) my calculator tells me that 28 sessions at £65 each would cover it neatly. How many whitenings could a beauty spa do in

\section{'We spend an enor- mous amount of time and energy ... attempting to define oral health'} the only way in which a case can be brought.

What I find fascinating about this process is that it is exactly the position that we were in with denturism a few years ago. Denturism was the somewhat derogatory term used for the provision of dentures, usually but not exclusively full-full dentures, by dental technicians who had set up business precisely to undertake this unlawful practising of dentistry. This small group has now morphed into clinical dental technicians and are regarded as valued and legitimate members of the dental team. Yet in the days of denturists, the dental profession expressed frequent irritation and resentment that 'these people' could carry on their business quite openly and without sanction from the GDC. Then, as now, unless a disgruntled patient complained to the Council and was prepared to testify, nothing could be done.

A further intriguing aspect of denturism was that so few clients did complain. The question was often asked as to why this was, since surely it was better to go to a dentist? The answers were not so surprising. It was dentists who had been responsible for extracting all the teeth that led to the patient needing dentures, so to find someone who wasn't a dentist seemed to be a good idea. This despite the prostheses being provided privately rather than on the NHS. Perhaps another interesting angle on why there were so few disgruntled customers.

We spend an enormous amount of time and energy within the profession attempting to define oral health. So one cannot help wondering what the average member of the public thinks of as oral health and whether or not they always associate it with dentists, or dental professionals. In the same way that in the time of denturism clients presumably were unaware that their 'clinicians' were not GDC registered (or indeed who or what the GDC was), one wonders if people in general give more than a passing thought to whether or not a beauty therapist needs to have any competency other than that which she or he demonstrated on the patient's friend, colleague or family member in making their smile look amazing. It is about appearance after all; on this basis, is applying lipstick an oral health activity?

I am not suggesting that we start lobbying for a new category of dental care professional called a whitening operative, but I do think it is worth us taking a pause to consider what the public's perception of tooth whitening is, and whether this tells us something important about their perception of oral health. With a shift away from the need to treat so much caries, the importance of appearance as an essential element of self-esteem and of wellbeing needs serious consideration. The quest for good oral health takes many forms and we must be responsive to them all.

DOI: 10.1038/sj.bdj.2015.791 